\title{
The use of cognitive behavioral therapy-based coping strategies in dealing with examination- related stress at medical school
}

This article was published in the following Dove Press journal:

Advances in Medical Education and Practice

26 September 2016

Number of times this article has been viewed

\author{
Aamer Mughal \\ Alok Prasad \\ Imran Ahmed \\ Farheen Ebrahim \\ Syed Mustafa Ali Ahmad \\ Faculty of Medicine, Imperial College \\ London, London, UK
}

Correspondence: Alok Prasad Faculty of Medicine, Imperial College London, Level 2, Faculty Building, South Kensington Campus, London SW7 2AZ, UK

Email alok.prasadI I@imperial.ac.uk

\section{Dear editor}

We note with great interest the work of Kötter and Niebuhr, ${ }^{1}$ with regard to reducing examination-related stress in medical students through short-term coaching. We highly commend their efforts to provide an evidence base for techniques that have been suggested in the literature. We would however argue that the use of coaching such as wingwave ${ }^{\circledR}$ may perhaps be too impractical and expensive to be used on a regular basis, and that the long-term efficacy of the approach is unclear. We would encourage further work into other methods and would specifically welcome trials comparing these techniques to the coaching described by Kötter and Niebuhr.

Examples of the other methods include introduction of elective courses specializing in the teaching of coping strategies, such as breathing exercises, social coping skills, and elements of cognitive behavioral therapy. Not only would this aid in the reduction of stress related to examinations, but also this could equip future doctors with a mental framework that may help them deal with future stressful situations. ${ }^{2}$ Evidence of their efficacy comes from the study of Pereira et al, ${ }^{3}$ which looked at the benefits of these elective courses, with the further addition of reflective practices and psychoanalysis. They found that " $67 \%$ reported less symptoms of stress at the end of the [elective] course". ${ }^{3}$

Furthermore, there has been a movement in recent years promoting the benefits of alternative self-care therapies. ${ }^{2}$ Arguably, the most well known of these include "mindfulness", "a cognitive style that facilitates non-judgemental awareness"4 and allows users to notice symptoms of stress and anxiety much earlier than they normally would, that Slonim et $a^{5}$ found to have "the potential ... to decrease medical student distress and enhance well-being".

We look forward to seeing the response of the academic community, and hope sincerely that an effective solution may be found to this neglected problem.

\section{Disclosure}

The authors report no conflicts of interest in this communication. 


\section{References}

1. Kötter T, Niebuhr F. Resource-oriented coaching for reduction of examination-related stress in medical students: an exploratory randomized controlled trial. Adv Med Educ Pract. 2016;7:497-504.

2. Dyrbye LN, Thomas MR, Shanafelt TD. Medical student distress: causes, consequences, and proposed solutions. Mayo Clin Proc. 2005;80(12):1613-1622.
3. Pereira MAD, Barbosa MA, de Rezende JC, Damiano RF. Medical student stress: an elective course as a possibility of help. BMC Res Notes. $2015 ; 8: 430$.

4. Kostanski M, Hassed C. Mindfulness as a concept and a process. Aust Psychol. 2008;43(1):15-21.

5. Slonim J, Kienhuis M, Di Benedetto M, Reece J. The relationships among self-care, dispositional mindfulness, and psychological distress in medical students. Med Educ Online. 2015;20:27924.

Dove Medical Press encourages responsible, free and frank academic debate. The content of the Advances in Medical Education and Practice 'letters to the editor' section does not necessarily represent the views of Dove Medical Press, its officers, agents, employees, related entities or the Advances in Medical Education and Practice editors. While all reasonable steps have been taken to confirm the content of each letter, Dove Medical Press accepts no liability in respect of the content of any letter, nor is it responsible for the content and accuracy of any letter to the editor.

Advances in Medical Education and Practice

Dovepress

\section{Publish your work in this journal}

Advances in Medical Education and Practice is an international, peerreviewed, open access journal that aims to present and publish research on Medical Education covering medical, dental, nursing and allied health care professional education. The journal covers undergraduate education, postgraduate training and continuing medical education including emerging trends and innovative models linking education, research, and health care services. The manuscript management system is completely online and includes a very quick and fair peer-review system. Visit http://www.dovepress.com/testimonials.php to read real quotes from published authors.

Submit your manuscript here: http://www.dovepress.com/advances-in-medical-education-and-practice-journal 